\title{
DNA Sequence Analysis of Microsatellite Markers Enhances Their Efficiency for Germplasm Management in an Italian Olive Collection
}

\author{
Innocenzo Muzzalupo and Nicola Lombardo \\ C.R.A.-Experimental Institute for Olive Growing, c. da Li Rocchi, 87036 Rende (CS), Italy
}

Aldo Musacchio
University of Calabria, Department of Ecology, 87036 Rende (CS), Italy

Maria Elena Noce

C.R.A.-Experimental Institute for Olive Growing, c. da Li Rocchi, 87036 Rende (CS), Italy

Giuseppe Pellegrino

University of Calabria, Department of Ecology, 87036 Rende (CS), Italy

Enzo Perri ${ }^{1}$

C.R.A.-Experimental Institute for Olive Growing, c. da Li Rocchi, 87036 Rende (CS), Italy

Ashif Sajjad

University of Calabria, Department of Chemistry, 87036 Rende (CS), Italy

AdDitional INDEX words. Olea europaea, Apulia olive germplasm collection, cultivar genotyping

\begin{abstract}
Genetic diversity studies using microsatelite analysis were carried out in a set of 39 accessions of Olea europaea $\mathrm{L}$., corresponding to the majority of the regional autochthon germplasm in Apulia. Samples of olive leaves were harvested from plants growing in the olive germplasm collection of the Consiglio per la Ricerca e Sperimentazione in Agricoltura (C.R.A.) - Istituto Sperimentale per l'Olivicoltura at Rende in Cosenza Italy. Herein, we evaluated the extent to which microsatellite analysis using electrophoresis was capable of identifying traditional olive cultivars. In addition, the DNA sequence of all amplicons was determined and the number of repeat units was established for each sample. Using five loci, electrophoretic analysis identified 24 genotype profiles, while DNA sequence analysis detected 28 different genotype profiles, identifying $54 \%$ of cultivars. The remaining $46 \%$ were composed of seven different accession groups containing genetically indistinguishable cultivars, which are presumably synonyms. This study demonstrates the utility of microsatellite markers for management of olive germplasm and points out the high level of polymorphisms in microsatellite repeats when coupled with DNA sequence analysis. The establishment of genetic relationships among cultivars in the Apulian germplasm collection allows for the construction of a molecular database that can be used to establish the genetic relationships between known and unknown cultivars.
\end{abstract}

The origin of olive trees in the Mediterranean basin is unclear, but is probably associated with a multi-local domestication of cultivated forms, as recent experiments with molecular markers have demonstrated (Besnard and Bervillé, 2000; Besnard et al., 2001). Since olives have been cultivated in all Mediterranean basin countries for millennia, there are likely to be a large number of synonymic and homonymic cultivars. At present, the extent of genetic variability in Italy and other olive-growing countries remains undefined. Owing to the beneficial properties of olive oil for human health (Visioli et al., 2005) and to the presence of edible fruits, olives have become one of the most important crops in this area. Olive plants have been vegetatively propagated by local populations since the Grecian age to take advantage of the best genetic complement derived from genomic mutations and random crosses. Therefore, each Mediterranean country hosts a

Received for publication 19 Sept. 2005. Accepted for publication 22 Feb. 2006 This research was supported by Apulia region, Assessorato Agricoltura e Foreste and C.R.A. as ordinary research.

${ }^{1}$ To whom reprint requests should be addressed; tel. +39-0984-402011; fax +390984-402099; e-mail: eperri@ irsaolivicoltura.it large number of cultivated olive varieties. The undefined genetic nature of olive germplasm gives rise to several problems for olive nurseries and, likewise, the criteria needed to properly classify and exploit olive products (Protected Designation of Origin, Protected Geographical Indication) like canned olives and oil are also unclear.

Olive are of significant commercial relevance: the Mediterranean basin harbors many cultivars of olive trees and this region alone produces $99 \%$ and consumes $87 \%$ of the world's olive oil (Loumou and Giourga, 2003). Thus, a solution for this problem is highly desirable. Standardized, reliable molecular methods have the capacity to eliminate ambiguities in identification of cultivars and to elucidate the potential existence of homonyms (one denomination for several genotypes) or synonyms (one genotype with several denominations).

Although in the Mediterranean basin olives are usually cultivated using traditional methods over large surfaces (about 7 million ha), the risk of genetic erosion of an inadequately characterized germplasm nonetheless exists (Khadari et al., 2003). In fact, there is a diffuse tendency to substitute traditional orchards with new plantations composed of only a few cultivars chosen on the basis of the agro-alimentary characteristics required by the 
target market. Consequently, in most cultivation areas rarefaction of the minor cultivars occurs, which can be considered as a threat in terms of biodiversity. Therefore, to look for alternative sources of material useful for increasing production and/or quality and to preserve minor cultivars as well as wild oleaster (O. europaea ssp. sylvestris Hoffgg et Link) and feral olive trees (originating either from varieties or from hybridization between a variety and an oleaster), which are a natural reserve of genetic diversity, efforts should be made to collect and characterize the olive germplasm.

At the same time, it would be important to improve the ex situ plant germplasm collection and utilize it to adequately characterize all accessions and develop future breeding programs. In this respect, several Mediterranean countries have promoted international olive germplasm collections, including Cordoba, Spain; Porquerolles, France; Marrakesh, Morocco; and Cosenza, Italy, which hosts most of the Mediterranean cultivars.

The Italian germplasm collection is large and variegated on a regional scale, because each region has gradually selected cultivars that were subjected to progressive adaptation. In fact, this has been recognized by the European Council Regulation (EEC) 2081/92 on the Protected Designation of Origin and Protected Geographical Indication, thus reinforcing the need to institute a molecular database for Italian olive germplasm. Based on estimates by the FAO Plant Production and Protection Division, Olive Germplasm (Bartolini et al., 1998; State of Italy, 1994), the collection contains more than 800 different cultivars. It therefore represents an important reserve of genetic diversity for the entire Mediterranean basin.

Large efforts have been made to characterize olive germplasm using different types of biochemical and molecular markers. Previous studies have used isozymes (Lumaret et al., 2004; Perri et al., 1995), RAPDs (Belaj et al., 2002, 2003a; Fabbri et al., 1995; Fodale et al., 2006; Lombardo et al., 2003, 2004; Perri et al., 2000; Wiesman et al., 1998), AFLPs (Angiolillo et al., 1999), ISSR and sequence analysis of nuclear ribosomal internal transcribed spacer 1 (Hesse et al., 2000), mitochondrial RFLPs (Besnard and Bervillé, 2000), and chloroplast RFLPs (Besnard and Berville, 2002; Besnard et al., 2002).

More recently, several microsatellites have been isolated from olives (Carriero et al., 2002; Cipriani et al., 2002; De la Rosa et al., 2002; Rallo et al., 2000; Sefc et al., 2000) and, at present, it has become common to utilize these markers in conjunction with other molecular markers (Belaj et al., 2003b; Godino et al., 2005; Khadari et al., 2003; De la Rosa et al., 2003; Wu et al., 2004). SSR markers are easily amplified by PCR and can thus be used on non-invasively sampled material; the results are also highly reproducible among different labs. SSRs are co-dominant markers, showing a large number of polymorphisms per primer set, and are thus very informative. Almost all the reports of cultivar identification using SSRs assessed differences in the length of the amplified alleles (Belaj et al., 2003b; Godino et al., 2005; Khadari et al., 2003; De la Rosa et al., 2003; Wu et al., 2004).

In the present paper we report the identification, using five SSR markers, of traditional olive cultivars from the Apulia region (Italy), which is a major area for olive cultivation in Italy with a strategic geographical location in the Mediterranean basin. We also show, by DNA sequence analysis of microsatellite alleles, that a very high degree of polymorphism is present, and that alleles with an identical length may have a different repeated motif. Further analysis on the genetic significance of these polymorphisms is needed.

\section{Material and Methods}

OLIVE GERMPLASM COLLECTION. Thirty-nine accessions of olive plants were used, corresponding to the majority of the regional autochthon Apulian germplasm (Table 1). Samples of olive leaves were harvested from plants growing in the olive germplasm collection of the C.R.A.-Istituto Sperimentale per l'Olivicoltura of Rende, Cosenza, located along the Ionian coasts near Mirto-Crosia (Calabria region, southern Italy).

To evaluate intra-cultivar variability, we analyzed $10 \%$ of the accessions by verifying that the individuals belonging to the same cultivar showed identical genotypes (Lombardo et al., 2004). Among the 39 accessions studied, six cultivars, 'Cellina di Nardò', 'Cima di Mola', 'Coratina', 'Ogliarola Barese', 'Ogliarola di Lecce', and 'Pizzuta', are cultivated in the main production areas over a large surface (several thousand hectares), and are the most relevant for the regional agricultural economy. The cultivars Bella di Cerignola, Ogliarola Garganica, Peranzana, Rotondella, and Sant'Agostino cover several thousand hectares, whereas the remaining 28 cultivars are located in small areas and represent an important genetic reserve for the autochthon Apulian germplasm (Lombardo et al., 2004).

DNA EXtraction. Total genomic DNA was extracted from fresh leaves using the CTAB method according to Muzzalupo and Perri (2002). After extraction, samples were treated with RNase A (Sigma Chemical Co., St. Louis) for $30 \mathrm{~min}$ at $37^{\circ} \mathrm{C}$ and run on $0.8 \%$ (w/v) agarose gels (FMC BioProducts, Rockland, Maine) in 1X Tris-borate-EDTA (TBE) buffer in the presence of ethidium bromide $\left(1 \mu \mathrm{g} \cdot \mathrm{mL}^{-1}\right)$. A DNA weight molecular marker (Sigma Chemical Co.) was used to estimate the concentration of samples.

DNA AMPLIFICATION. Several primer pairs from previously published studies were evaluated. Among the primer sets designed by Carriero et al. (2002), GAPU45, GAPU59, and GAPU71A were assessed due to the relatively large number of different alleles amplified. For the same reason, the UDO01 and UDO39 loci described by Cipriani et al. (2002) were also amplified.

PCR reactions were carried out in $50 \mu \mathrm{L}$ containing $20 \mathrm{ng}$ of DNA, $10 \mathrm{~mm}$ Tris- $\mathrm{HCl} \mathrm{pH} 8.0,1.5 \mathrm{~mm} \mathrm{MgCl}_{2}, 50 \mathrm{~mm} \mathrm{KCl}$, $0.2 \mathrm{~mm}$ dNTPs, $0.25 \mu \mathrm{M}$ forward and reverse primers, and 0.05 units of Taq DNA polymerase (Roche Diagnostics, Mannheim, Germany).

PCR conditions comprised an initial denaturing step at $94{ }^{\circ} \mathrm{C}$ for $3 \mathrm{~min}$, followed by 40 cycles of $94^{\circ} \mathrm{C}$ for $30 \mathrm{~s}, 60^{\circ} \mathrm{C}$ for 40 $\mathrm{s}$ and $72{ }^{\circ} \mathrm{C}$ for $30 \mathrm{~s}$ plus a final extension at $72{ }^{\circ} \mathrm{C}$ for $5 \mathrm{~min}$ in a GeneAmp PCR 9600 (PE Applied Biosystems, Foster City, Calif.). PCR products were analyzed using a 2100 Bioanalyzer (Agilent Tecnologies, Waldbronn, Germany) by using the DNA 500 LabChip Kit (Burns et al., 2003), which provides an estimate of the length of any amplified product.

SEQUENCING. All the SSR amplification products were subjected to direct DNA sequence analysis since different alleles may have similar or even identical lengths, but different repeating units. Consequently, the exact number of repeat units was established for every sample. PCR products were run in $3 \%(\mathrm{w} / \mathrm{v})$ agarose gels (FMC BioProducts) in TBE 1X buffer in the presence of ethidium bromide $\left(1 \mu \mathrm{g} \cdot \mathrm{mL}^{-1}\right)$ at $100 \mathrm{~V}$ for $4 \mathrm{~h}$. Amplified bands were excised from the gel and purified using the QIAquick Gel Extraction kit (Qiagen Spa, Milan, Italy). The purified products were analyzed using a 2100 Bioanalyzer (Agilent Tecnologies) on a DNA 500 Chip (Burns et al., 2003) and the yield of template for any allele was estimated for sequencing reactions. 
Table 1. List of the 39 olive accessions analyzed from the olive germplasm collection of the Apulia region of Italy, including their local synonyms and the main production areas.

\begin{tabular}{|c|c|c|}
\hline Accessions & Local synonyms ${ }^{z}$ & Cultivation area \\
\hline Bella di Cerignola ${ }^{z}$ & Grossa di Spagna, Oliva a Prugna, etc. & Bari, Foggia, Lecce, Taranto \\
\hline Bella di Spagnaz & Belle d'Espagne, Belle of Spain & Foggia \\
\hline Butirra Melpignanoz & --- & Lecce \\
\hline Carmelitana $^{\mathrm{z}}$ & --- & Bari, Foggia \\
\hline Cazzinicchio $^{z}$ & --- & Bari \\
\hline Cellina di Nardòz & Cafarella, Cellina Inchiastra, etc. & Bari, Brindisi, Lecce, Taranto \\
\hline Cerasellaz & Bicarrese, Riccia, Rotondella & Bari, Foggia, Taranto \\
\hline Cima di Molaz & Cima di Monopoli, Molese, etc. & Bari, Brindisi \\
\hline Coratinaz $^{z}$ & Cima di Corato, Racemo, etc. & Apulia region \\
\hline Dolce di Cassanoy & --- & Bari \\
\hline Dolce d'Andriaz & Dolce di Sannicandro, Dolce di Puglia & Bari, Foggia, Lecce \\
\hline Dolce Melez & Mele & Bari \\
\hline Frangiventoz $^{z}$ & Cipressino, Olivo di Pietrafitta, etc. & Lecce, Taranto \\
\hline Lezzey & Oliastro, Oliastro di Conversano & Bari, Brindisi, Taranto \\
\hline Marinese ${ }^{z}$ & Cima di Bitonto, Ogliarola Barese, Ogliarola Garganica, etc. & Foggia \\
\hline Mele $^{z}$ & Amele, Melo Dolce, etc. & Bari, Brindisi, Taranto \\
\hline Moraw $^{w}$ & --- & Bari \\
\hline Morellona di Greciaz & Nera di Grecia & Lecce \\
\hline Nociaraz & --- & Bari, Brindisi, Taranto \\
\hline Nolcaz & Annolca, Dolce di Barbarano, etc. & Apulia region \\
\hline Nzimbiboloz & --- & Foggia \\
\hline Ogliarola Barese ${ }^{z}$ & Cima di Bitonto & Bari, Brindisi, Foggia, Lecce \\
\hline Ogliarola Garganicaz & Cima di Bitonto & Foggia \\
\hline Ogliarola di Leccez & Ogliarola Salentina, Pizzuta, Chiarita, etc. & Apulia region \\
\hline Oliastroy & Olivastro di Conversano, Lezze & Bari, Brindisi, Taranto \\
\hline Oliva Dolce di Barbaranoz & Nolca & Lecce \\
\hline Oliva Rossa ${ }^{x}$ & --- & Bari \\
\hline Pasola $^{z}$ & Fasola, Passula, Calabrese, Frasola, etc. & Apulia region \\
\hline Pasola d'Andriay & -- & Bari \\
\hline Peppino $\mathrm{Leo}^{z}$ & --- & Bari \\
\hline Peranzanaz $^{z}$ & Provenzale, Francese, Tondina, etc. & Bari, Foggia, Lecce, Taranto \\
\hline Pizzuta $^{z}$ & Ogliarola di Lecce & Bari, Brindisi, Lecce, Taranto \\
\hline Racemo $^{z}$ & Coratina & Bari \\
\hline Rotondella ${ }^{z}$ & --- & Foggia \\
\hline San Benedetto ${ }^{z}$ & --- & Lecce \\
\hline Sant'Agostino ${ }^{2}$ & Grossa Andriesana, Oliva Grossa, etc. & Apulia region \\
\hline Simona $^{z}$ & --- & Bari \\
\hline Termite di Bitetto ${ }^{z}$ & Cima di Bitetto, Mele di Bitetto, etc. & Bari, Brindisi, Taranto \\
\hline Toscanina $^{z}$ & Oliva a Grappa & Brindisi \\
\hline
\end{tabular}

zBartolini et al., 1998.

yLombardo et al., 2004.

xState of Italy, 1994.

wFerrara and Lamparelli, 1995.

Sequence analysis was performed utilizing Sequencing Analysis 3.7 software (PE Applied Biosystems). Alleles of the same length were isolated from $3 \%(\mathrm{w} / \mathrm{v})$ agarose gels. The PCR products were cloned using a PCR-ScriptTMAMP Cloning Kit (Stratagene, La Jolla, Calif.) following the manufacturer's instructions. Plasmid DNA was isolated using a NucleoSpin Plasmid kit (Macherey-Nagel AG, Oensingen, Switzerland) and the inserts were sequenced.

The sequencing reactions were performed in a GeneAmp PCR 9600 (PE Applied Biosystems) using a BigDye Terminator v.1.1 Cycle Sequencing Kit (PE Applied Biosystems) utilizing 25 cycles of $96^{\circ} \mathrm{C}$ for $10 \mathrm{~s}, 50^{\circ} \mathrm{C}$ for $5 \mathrm{~s}$, and $60{ }^{\circ} \mathrm{C}$ for $4 \mathrm{~min}$ and then loaded on a ABI Prism 310 Sequencer (PE Applied Biosystems).

Data analysis. The expected heterozygosity $(\mathrm{He})$ of each microsatellite was calculated according to the formula $\mathrm{He}=1$ - $\sum p i^{2}(\mathrm{Nei}, 1973)$, where $p i$ is the allele frequency for the $i^{\text {th }}$ allele at one locus and $\mathrm{He}$ is the probability that two alleles from the same locus are different when chosen at random. He and observed heterozygosity $(\mathrm{Ho})$ were calculated using POPGENE 32 software (Yeh et al., 1997).

By using the same software to calculate the effective allele number or Nef (Kimura and Crow, 1964), the reciprocal of homozygosity was estimated (Hartl and Clark, 1989); Nei's genetic identities were calculated to evaluate the inter-cultivar differentiation and the genetic distances among cultivars. The number of alleles detected (Nde, counts the number of alleles with nonzero frequency) and exclusive (Nex, counts the number of alleles present) with and without sequencing SSR loci was calculated using the same software (Table 2). 
Table 2. SSR lociin 39 accessions of olive germplasm from the collection of the Apulia region of Italy. For each locus, the number of detected (Nde), effective (Nef), and exclusive (Nex) alleles was obtained with and without sequencing. Nde, Nef, and Nex were calculated using POPGENE 32 software.

\begin{tabular}{lrrrrrrr}
\hline & \multicolumn{3}{c}{ With sequencing } & & \multicolumn{3}{c}{ Without sequencing } \\
\cline { 2 - 4 } Locus & Nde & Nef & Nex & & Nde & Nef & Nex \\
\hline GAPU45 & 5.00 & 4.16 & 0.00 & & 4.00 & 2.44 & 0.00 \\
GAPU59 & 6.00 & 3.68 & 1.00 & & 4.00 & 2.13 & 0.00 \\
GAPU71A & 6.00 & 2.66 & 1.00 & & 5.00 & 2.43 & 1.00 \\
UDO01 & 2.00 & 1.62 & 0.00 & & 2.00 & 1.62 & 0.00 \\
UDO39 & 9.00 & 5.11 & 1.00 & & 9.00 & 5.11 & 1.00 \\
Total & 28.00 & 17.23 & 3.00 & & 24.00 & 13.73 & 2.00 \\
Mean & 5.60 & 3.45 & --- & & 4.80 & 2.75 & --- \\
SD & 2.51 & 1.35 & --- & & 2.59 & 1.36 & -- \\
\hline
\end{tabular}

TFPGA software version 1.3 (Miller, 1997) was used to construct the phenogram in Fig. 1. This procedure is designed to provide users with a graphical representation of Nei's (1972) genetic distance data from which relationships may be inferred. Swofford and Olsen (1990) provide an excellent summary of the unweighted pair-group method using an arithmetic average (UPGMA) algorithm and the assumptions of this clustering method.

\section{Results}

OLIVE SSR LOCI AND GENETIC DIVERSITY. After an initial screening, five primer pairs were chosen for further analysis based on their polymorphic index and reproducibility of amplification. The DNA sequence of all amplicons was determined and the exact number of repeat units was established for each sample. In fact, we observed that some alleles showed the same length but different sequences due to a sequence variant that interrupted the tandem repeat unit motif. A total of 28 alleles was found in the five loci (Table 2), with an average of 5.6 alleles/locus, ranging from 2 alleles/locus at UDO01 to 9 alleles/locus at UDO39. This is comparable to the number of alleles among olive cultivars reported by Rallo et al. (2000), but somewhat lower than that published by Khadari et al. (2003), probably because it included a large number of foreign cultivars. Interestingly, only 24 of the 28 alleles were distinguishable by electrophoretic analysis, with an average of 4.8 alleles/locus (Table 2), since these had the same length but minor nucleotide changes.

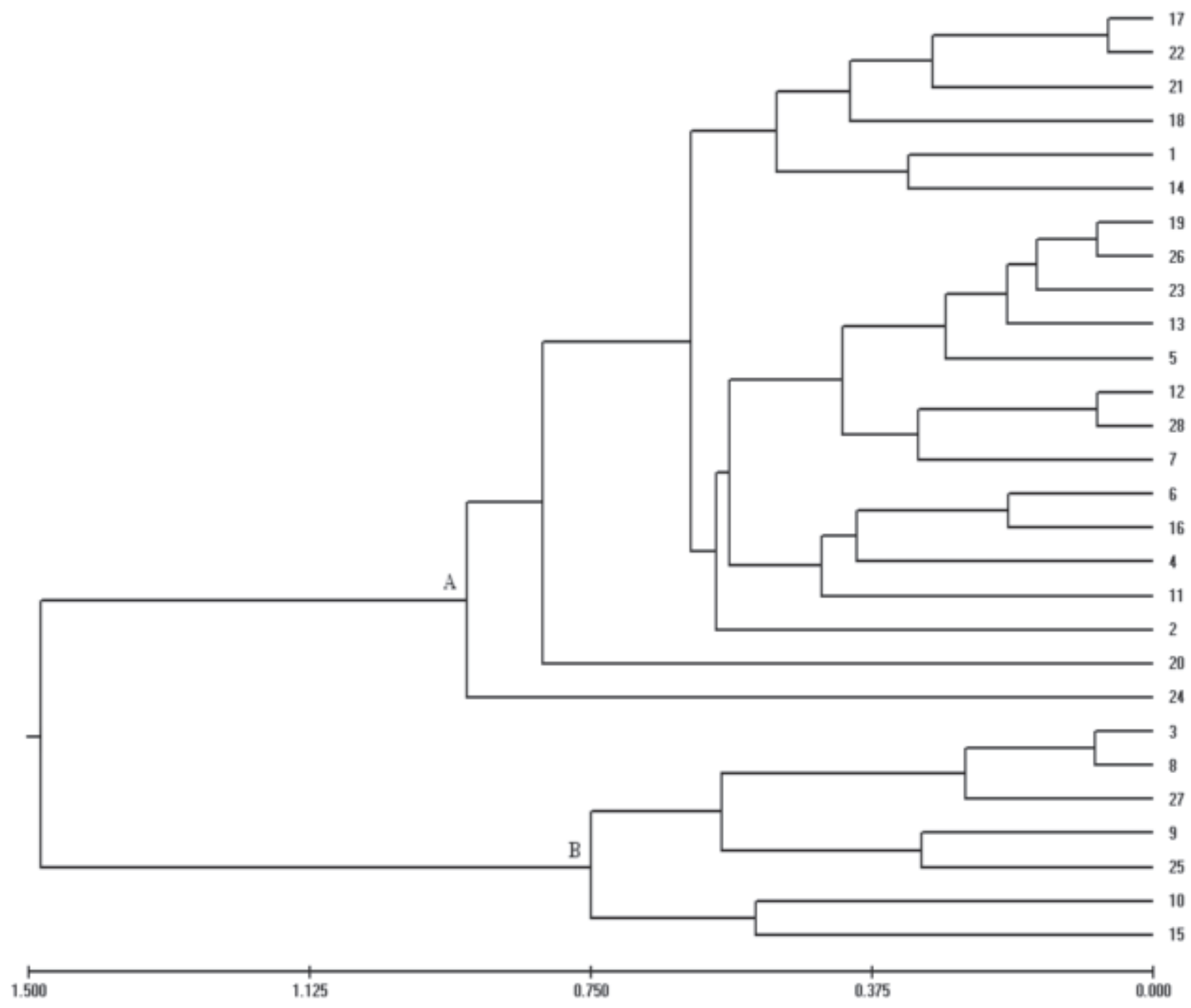

Fig. 1. Dendrogram of 28 olive genotypes generated by UPGMA cluster analysis based on Nei's (1972) genetic distances obtained using TFPGA software version 1.3. Genotype number corresponds to those reported in Table 4. Capital letters in the dendrogram correspond to different clusters. 
Table 3. Repeat motif and sequence size of the SSR amplification products employed in the characterization of olive accessions. For every locus only the variable sequence region is reported. The underlined nucleotides represent sequence variants detected by DNA sequence analysis.

\begin{tabular}{|c|c|c|}
\hline Locus & Size of allele (bp) & Sequence motif \\
\hline GAPU45 & $\begin{array}{l}183 \mathrm{~A} \\
183 \mathrm{~B} \\
185 \\
182 \\
196\end{array}$ & $\begin{array}{l}\text { C }(\mathrm{AG})_{7} \text { CTTCAAG } \\
\text { C(AG) }{ }_{8} \text { CTTCG } \\
\text { C(AG) }{ }_{8} \text { CTTCAAG } \\
\text { GTG }(\mathrm{AG})_{9} \\
\text { GTG }(\mathrm{AG})_{12} \mathrm{TG}(\mathrm{AG})_{3}\end{array}$ \\
\hline GAPU59 & $\begin{array}{l}208 \mathrm{~A} \\
208 \mathrm{~B} \\
212 \\
218 \\
222 \mathrm{E} \\
222 \mathrm{~F}\end{array}$ & $\begin{array}{l}\underline{\mathrm{AA}}(\mathrm{CT})_{10} \\
(\mathrm{CT})_{11} \\
(\mathrm{CT})_{13} \\
\mathrm{AA}(\mathrm{CT})_{15} \\
(\mathrm{CT})_{16} \mathrm{TTCT} \\
(\mathrm{CT})_{18}\end{array}$ \\
\hline GAPU71A & $\begin{array}{l}210 \mathrm{~A} \\
210 \mathrm{~B} \\
212 \\
214 \\
224 \\
228\end{array}$ & $\begin{array}{l}(\mathrm{AG})_{6} \mathrm{AAAG} \\
(\mathrm{AG})_{8} \\
(\mathrm{AG})_{9} \\
(\mathrm{AG})_{10} \\
(\mathrm{AG})_{15} \\
(\mathrm{AG})_{17}\end{array}$ \\
\hline UDO01 & $\begin{array}{l}140 \\
144\end{array}$ & $\begin{array}{l}(\mathrm{CA})_{8} \mathrm{AA} \\
(\mathrm{CA})_{11}\end{array}$ \\
\hline UDO39 & $\begin{array}{l}108 \\
142 \\
146 \\
164 \\
170 \\
173 \\
175 \\
184 \\
188\end{array}$ & $\begin{array}{l}\text { AA }(\text { ATAC })_{2}(\mathrm{AT})_{2} \\
(\mathrm{AT})_{7}(\mathrm{GT})_{5}(\mathrm{GC})_{6} \mathrm{~A}(\mathrm{CGTG})_{2} \mathrm{TTG} \\
(\mathrm{AT})_{7}(\mathrm{GT})_{8}(\mathrm{GC})_{4} \mathrm{~A}(\mathrm{GTGC})_{2} \mathrm{ATGTTG} \\
(\mathrm{AT})_{5}(\mathrm{GT})_{12}(\mathrm{GC})_{3}(\mathrm{GT})_{2} \mathrm{GCAT}(\mathrm{GC})_{2}(\mathrm{GT})_{3} \mathrm{GCGTGCATGTTG} \\
(\mathrm{AT})_{5}(\mathrm{GT})_{11}(\mathrm{GC})_{3}(\mathrm{GT})_{2} \mathrm{GC}(\mathrm{GT})_{3} \mathrm{GCGT}(\mathrm{GC})_{2}(\mathrm{GT})_{3} \mathrm{GCGTGCATGTTG} \\
(\mathrm{AT})_{8}(\mathrm{GT})_{20}(\mathrm{GC})_{2}(\mathrm{GTGC})_{4} \mathrm{GTG} \\
(\mathrm{AT})_{8}(\mathrm{GT})_{21}(\mathrm{GC})_{2}(\mathrm{GTGC})_{4} \mathrm{GTG} \\
(\mathrm{AT})_{9}(\mathrm{GT})_{16}(\mathrm{GC})_{2}(\mathrm{GTGC}) 2(\mathrm{GC})_{5}(\mathrm{GTGC})_{3} \mathrm{GTGTTG} \\
(\mathrm{AT})_{5}(\mathrm{GT})_{13}(\mathrm{GC})_{3}(\mathrm{GT})_{2} \mathrm{GC}(\mathrm{GT})_{3} \mathrm{GCGT}(\mathrm{GC})_{2}(\mathrm{GT})_{3} \mathrm{GCAT}(\mathrm{GC})_{2}(\mathrm{GT})_{3} \text { GCGTGCATGTTG }\end{array}$ \\
\hline
\end{tabular}

The size range and the sequenced repeat motifs for all loci are reported in Table 3 . The shortest allele among these five loci was 108 bp in length in UDO39, while the longest allele was 228 bp in GAPU71A. As mentioned above, four alleles were not distinguishable by electrophoresis and showed different DNA sequences (Table 3 ). These included allele $183 \mathrm{~A} / 183 \mathrm{~B}$ bp at GAPU45, alleles 208A/208B bp and 222E/222F bp at GAPU59, and alleles 210A/210B bp at GAPU71A (Table 3).

The lowest allelic frequency (0.013) was observed in alleles 222F bp of GAPU59 and 228 bp GAPU71A in 'Cellina di Nardó' and 142 bp at UDO39 in 'Butirra di Melpignano', whereas allele $144 \mathrm{bp}$ of the less polymorphic locus UDO01 showed the highest frequency (0.744). Three alleles were present only once in all the cultivars analyzed (Table 4).

The highest genotypic frequency (0.74) was observed at UDO01 for the 144-144 genotype, while the lowest frequencies (0.03) were detected for the 208A-208A, 208A-222F, and 218-218 genotypes at GAPU59, obtained for 'Frangivento', 'Cellina di Nardó', and 'Toscanina', respectively; for the 210A-224, 210B210B, 212-214, and 214-228 genotypes at the locus GAPU71A observed in 'Mora', 'Simona', 'Peranzana', and 'Cellina di Nardó', respectively; and for the 108-142, 108-164, 108-173, 108-175, 108-188, 146-146, 164-164, 170-173, 173-173, 173-184, 184-184, and 188-188 genotypes at the UDO39 locus in 'Butirra di Melpignano', 'Simona', 'Peranzana', 'Dolce di Cassano', 'Cellina di Nardó', 'Oliva Dolce di Barbarano', 'Toscanina', 'Nociara', 'San Benedetto', 'Frangivento', 'Carmelitana', and 'Rotondella', respectively (Table 4).
The observed heterozygosity for the 39 cultivars ranged from 0.00 at UDO01 to 0.77 at the GAPU45 locus, which was lower than the expected value. Table 5 shows the observed and expected heterozygosities obtained by either electrophoretic or DNA sequence analysis.

GENETIC RELATIONSHIPS BETWEEN OLIVE CULTIVARS. 28 unique genotype profiles were obtained using only five loci (Table 4), which identified 54\% of the cultivars analyzed (genotypes 1-21). The remaining $46 \%$ probably comprises seven different accession groups in which the cultivars are genetically indistinguishable from one another, potentially representing cases of synonymy (Table 4). The first group comprises 'Bella di Spagna' and 'Bella di Cerignola' (genotype 22); the second, 'Cerasella', 'Nolca', and 'Olivo Mele' (genotype 23); the third, 'Cima di Mola', 'Ogliarola di Lecce', and 'Pizzuta' (genotype 24); the fourth, 'Coratina' and 'Racemo' (genotype 25); the fifth, 'Dolce d'Andria' and 'Dolce Mele' (genotype 26); the sixth, 'Lezze', 'Oliastro', and 'Oliva Rossa' (genotype 27); and the last, 'Marinese', 'Ogliarola Barese', and 'Ogliarola Garganica' (genotype 28). These possible cases of synonymy were in agreement with previous data using RAPDs (39 primers) and morphological (36 parameters) analysis (Lombardo et al., 2004) obtained using the same set of olive trees.

Genotype 3 showed the highest percentage of shared alleles (90\%) with genotype 8 , as was the case for genotype 12 with 28, 17 with 22 , and 19 with 26, while genotype 1 showed the lowest percentage $(0 \%)$ with genotype 27 . Genotype 4 showed the highest percentage of shared alleles with genotypes 25 and 27 , while genotype 6 showed the highest percentage of shared 
Table 4. Molecular characterization of 39 olive accessions by sequencing of the amplicons from five SSR loci (GAPU45, GAPU59, GAPU71A, UDO01 and UDO39). Unique genotype (UG) profiles and the exclusive alleles (in bold) obtained from the combination of sequencing SSR loci are reported. Seven different accession groups (genotypes from 22 to 28) are genetically indistinguishable from one another.

\begin{tabular}{|c|c|c|c|c|c|c|}
\hline Accessions & GAPU45 & GAPU59 & GAPU71A & UDO01 & UDO39 & $\mathrm{UG}^{\mathrm{z}}$ \\
\hline Butirra di Melpignano & $182-196$ & $222 \mathrm{E}$ & 214 & 144 & $108-142$ & 1 \\
\hline Carmelitana & $183 \mathrm{~A}-196$ & 208A-208B & 214-224 & 144 & 184 & 2 \\
\hline Cazzinicchio & $183 \mathrm{~A}-183 \mathrm{~B}$ & 208B & $210 \mathrm{~A}-214$ & 140 & $108-184$ & 3 \\
\hline Cellina di Nardó & 196 & 208A-222F & 214-228 & 144 & $108-188$ & 4 \\
\hline Dolce di Cassano & 183B-185 & 208A-208B & $214-224$ & 144 & $108-175$ & 5 \\
\hline Frangivento & 196 & $208 \mathrm{~A}$ & 214 & 144 & $173-184$ & 6 \\
\hline Mora & $183 \mathrm{~A}-196$ & 208A-208B & $210 \mathrm{~A}-224$ & 144 & $108-170$ & 7 \\
\hline Morellona di Grecia & $183 \mathrm{~A}-183 \mathrm{~B}$ & 208B-222E & $210 \mathrm{~A}-214$ & 140 & $108-184$ & 8 \\
\hline Nociara & $183 \mathrm{~A}$ & $208 B-222 E$ & 210B-214 & 140 & $170-173$ & 9 \\
\hline Oliva Dolce di Barbarano & 183B & $222 \mathrm{E}$ & 214-224 & 140 & 146 & 10 \\
\hline Pasola & $182-196$ & $208 \mathrm{~A}-218$ & 214 & 144 & 175 & 11 \\
\hline Pasola d'Andria & $183 \mathrm{~A}-183 \mathrm{~B}$ & $208 \mathrm{~A}-208 \mathrm{~B}$ & $214-224$ & 144 & 170 & 12 \\
\hline Peppino Leo & 183B-182 & $208 \mathrm{~A}-218$ & 214 & 144 & 108 & 13 \\
\hline Peranzana & 183B-182 & 208B-222E & $212-214$ & 144 & $108-173$ & 14 \\
\hline Rotondella & 183B-196 & $208 B-222 E$ & 214 & 140 & 188 & 15 \\
\hline San Benedetto & $183 \mathrm{~A}-196$ & 208A-208B & 214 & 144 & 173 & 16 \\
\hline Sant'Agostino & $183 \mathrm{~A}-196$ & 208B & 210B-214 & 144 & 108 & 17 \\
\hline Simona & 182-196 & $208 B-222 E$ & $210 \mathrm{~B}$ & 144 & $108-164$ & 18 \\
\hline Termite di Bitetto & 183B-185 & 208B-218 & 214 & 144 & $108-170$ & 19 \\
\hline Toscanina & $183 \mathrm{~A}-182$ & 218 & 210B-214 & 144 & 164 & 20 \\
\hline Nzimbibolo & 182-196 & 208B-218 & $214-224$ & 144 & 108 & 21 \\
\hline Bella di Spagna & $183 \mathrm{~A}$ & 208B & 210B-214 & 144 & 108 & 22 \\
\hline Bella di Cerignola & $183 \mathrm{~A}$ & $208 B$ & 210B-214 & 144 & 108 & 22 \\
\hline Cerasella & 183B-196 & $208 \mathrm{~A}-208 \mathrm{~B}$ & 214 & 144 & $108-170$ & 23 \\
\hline Mele & 183B-196 & $208 \mathrm{~A}-208 \mathrm{~B}$ & 214 & 144 & $108-170$ & 23 \\
\hline Nolca & 183B-196 & 208A-208B & 214 & 144 & $108-170$ & 23 \\
\hline Cima di Mola & $183 \mathrm{~B}$ & 212 & 210B-214 & 144 & 175 & 24 \\
\hline Ogliarola di Lecce & 183B & 212 & 210B-214 & 144 & 175 & 24 \\
\hline Pizzuta & 183B & 212 & 210B-214 & 144 & 175 & 24 \\
\hline Coratina & $183 \mathrm{~A}-182$ & 208B & $210 B-224$ & 140 & 170 & 25 \\
\hline Racemo & $183 \mathrm{~A}-182$ & 208B & $210 B-224$ & 140 & 170 & 25 \\
\hline Dolce d'Andria & 183B-182 & $208 \mathrm{~A}-218$ & 214 & 144 & $108-170$ & 26 \\
\hline Dolce Mele & 183B-182 & $208 \mathrm{~A}-218$ & 214 & 144 & $108-170$ & 26 \\
\hline Lezze & $183 \mathrm{~A}-183 \mathrm{~B}$ & 208B-218 & $210 \mathrm{~A}$ & 140 & $146-184$ & 27 \\
\hline Oliastro & $183 \mathrm{~A}-183 \mathrm{~B}$ & 208B-218 & $210 \mathrm{~A}$ & 140 & $146-184$ & 27 \\
\hline Oliva Rossa & $183 \mathrm{~A}-183 \mathrm{~B}$ & 208B-218 & $210 \mathrm{~A}$ & 140 & $146-184$ & 27 \\
\hline Marinese & 183B-182 & 208A-208B & $214-224$ & 144 & 170 & 28 \\
\hline Ogliarola Barese & 183B-182 & $208 \mathrm{~A}-208 \mathrm{~B}$ & 214-224 & 144 & 170 & 28 \\
\hline Ogliarola Garganica & 183B-182 & 208A-208B & $214-224$ & 144 & 170 & 28 \\
\hline
\end{tabular}

${ }^{2}$ The numbers used coincide with the numbers used in the dendrogram of the germplasm from the collection of the Apulia region of Italy (Fig. 1).

alleles with genotype 25 . Therefore, the highest values of genetic identity (Nei, 1987) were observed between genotypes 17 and 22 (0.94), genotypes 3 and 8 (0.93), genotypes 12 and $28(0.93)$, and genotypes 19 and $26(0.93)$.

Genetic distances (Nei, 1972) were utilized to obtain a phenogram based on the UPGMA algorithm of clustering (Fig. 1). Two distinct clusters of olive cultivars were clearly recognizable. The first cluster included $74 \%$ of cultivars examined, while the second cluster contained $26 \%$ of cultivars.

\section{Discussion}

Our results show that SSR markers can be successfully used to characterize the collection of Apulian olive germplasm, using existing primers, without the expensive development of new markers. In fact, the SSR loci used in this work were previously selected based on their high polymorphic index (Carriero et al., 2002; Cipriani et al., 2002). Most importantly, it should be highlighted that the efficacy of classic microsatellite analysis by size comparison of alleles can be further enhanced by DNA sequence analysis, by allowing for the individuation of alleles not detectable by size analysis alone.

Almost all reports of cultivar identification using SSRs employed a greater number of primers with simple determination of the length of the amplified product. In the present report, we improved the specificity of this analysis by sequencing the amplicons from only five SSR loci. In fact, alleles with similar or even identical lengths may have different sequences. The presence of sequence variants within microsatellites, including single nucleotide polymorphisms (SNPs), could be particularly useful in the development of molecular markers for characterization of germplasm. The identification of 28 different genotypes and the 
Table 5. Analysis of molecular data of 39 olive accessions from the germplasm collection of the Apulia region of Italy by means of five SSR loci. Observed (Ho) and expected heterozygosity $(\mathrm{He})$ values were obtained from the combination of with and without sequencing SSR loci. Ho and He were calculated using POPGENE 32 software.

\begin{tabular}{lccccc}
\hline \multirow{2}{*}{ Locus } & \multicolumn{2}{c}{ With sequencing } & & \multicolumn{2}{c}{ Without sequencing } \\
\cline { 2 - 3 } \cline { 5 - 6 } \cline { 5 - 6 } Go & He & & Ho & He \\
GAPU45 & 0.77 & 0.76 & & 0.61 & 0.60 \\
GAPU59 & 0.67 & 0.73 & & 0.38 & 0.54 \\
GAPU71A & 0.59 & 0.62 & & 0.59 & 0.60 \\
UDO01 & 0.00 & 0.38 & & 0.00 & 0.39 \\
UDO39 & 0.49 & 0.80 & & 0.49 & 0.81 \\
Mean & 0.50 & 0.66 & & 0.41 & 0.59 \\
SD & 0.30 & 0.17 & & 0.25 & 0.15
\end{tabular}

detection of 21 cultivars with unique genotypes demonstrated by analysis of SSRs show that it is an efficient tool to genotype our collection of olive germplasm and may be useful to characterize additional accessions.

Among the cultivar groups showing shared genotypes, we can conclude that, as already inferred, they are in fact synonyms. By comparison of the molecular profiles obtained from the five SSR loci, we observed that the same genotype is shared among two or more cultivars in genotypes ranging from 22 and 28 (Table 4). Genotype 22 consisted of two accessions, 'Bella di Spagna' and 'Bella di Cerignola', which was in accordance with morphological and molecular analysis data (Lombardo et al., 2004), but in contrast with the survey carried out by Bartolini et al. (1998). Genotype 23 included three accessions ('Cerasella', 'Mele', and 'Nolca'), which is in agreement with morphological and molecular data (Lombardo et al., 2004), but in contrast to that reported by Bartolini et al. (1998). Genotype 24 comprises three accessions, namely 'Ogliarola di Lecce', 'Pizzuta', and 'Cima di Mola'. According to Bartolini et al. (1998) the 'Ogliarola di Lecce' and 'Pizzuta' accessions are synonyms. The results with 'Cima di Mola' are in contrast with the data of Bartolini et al. (1998), but in agreement with morphological observations and the results of RAPDs (Lombardo et al., 2004). The 'Coratina' and 'Racemo' accessions, belonging to genotype 25 , are synonyms according to literature data (Bartolini et al., 1998; Ferrara et al., 1995; Lombardo et al., 2004). Genotype 26 includes two accessions: 'Dolce di Andria' and 'Dolce Mele', which were identical according to morphological and RAPDs data (Lombardo et al., 2004), but in contrast to the survey carried out by Bartolini et al. (1998). Genotype 27 comprises three accessions, 'Lezze', 'Oliastro', and 'Oliva Rossa', which is in agreement with morphological observations and RAPDs analysis (Lombardo et al., 2004). Genotype 28 included the 'Marinese', 'Ogliarola Barese', and 'Ogliarola Garganica' accessions, which are synonyms according to available data (Bartolini et al., 1998; Lombardo et al., 2004). In fact, these names are local synonyms for 'Cima di Bitonto' (Bartolini et al., 1998). It is very common to attribute different names to the same cultivar. Therefore, characterization of synonyms is very important in order to avoid genotype redundancy and to maximize genetic diversity in olive germplasm collections.

This study confirmed the utility of molecular analysis of olive germplasm and demonstrated the high level of polymorphisms in microsatellites, which is further augmented by DNA sequence analysis by revealing polymorphisms present in the microsatellite repeat. This is an important consideration since the additional costs of DNA sequencing must be weighed against the additional benefits in terms of cultivar identification and classification. In fact, the observed variability may also be used to measure genetic distances among different entities and to affirm with reasonable certainty if homogeneous genetic entities are present.

Large efforts have been made in characterizing olive germplasm using different types of biochemical and molecular markers. Analysis of SSRs in cultivars in the Apulian germplasm collection allowed us to construct a molecular catalog that can be used to compare the molecular pattern of the various cultivars as well as to other samples of unknown origin, avoiding the collection of redundant genetic entities. The use of molecular markers like SSRs, in addition to other information, is imperative in order to build a database for cultivar analysis and for appropriate management of olive germplasm collections.

\section{Literature Cited}

Angiolillo, A., M. Mencuccini, and L. Baldoni. 1999. Olive genetic diversity assessed using amplified fragment length polymorphisms. Theor. Appl. Genet. 98:411-421.

Bartolini, G., G. Prevost, C. Messeri, and G. Carignani. 1998. Olive germplasm: Cultivars and world-wide collections, FAO Plant Production and Protection Div., Rome.

Belaj, A., Z. Satovic, H. Ismaili, D. Panatoti, L. Rallo, and I. Trujillo. 2003a. RAPD genetic diversity of Albanian olive germplasm and its relationships with other Mediterranean countries. Euphytica 130:387-395.

Belaj, A., Z. Satovic, G. Cipriani, L. Baldoni, R. Testolin, L. Rallo, and I. Trujillo. 2003b. Comparative study of the discriminating capacity of RAPD, AFLP and SSR markers and their effectiveness in establishing genetic relationships in olive. Theor. Appl. Genet. 107:736-744.

Belaj, A., Z. Satovic, L. Rallo, and I. Trujillo. 2002. Genetic diversity and relationships in olive (Olea europaea L.) germplasm collections as determined by randomly amplified polymorphic DNA. Theor. Appl. Genet. 105:638-644.

Besnard, G. and A. Bervillé. 2000. Multiple origins for Mediterranean olive (Olea europaea L. ssp. europaea) based upon mitochondrial DNA polymorphisms. Life Sci. 323:173-181.

Besnard, G. and A. Bervillé. 2002. On chloroplast DNA variation in the olive (Olea europaea L.) complex: Comparison of RFLP and PCR polymorphism. Theor. Appl. Genet. 104:1157-1163.

Besnard, G., B. Khadari, P. Baradat, and A. Bervillé. 2002. Olea europaea (Oleaceae) phylogeography based on chloroplast DNA polymorphism. Theor. Appl. Genet. 104:1353-1361.

Besnard, G., P. Baradat, and A. Bervillé. 2001. Genetic relationships in the olive (Olea europaea L.) reflect multilocal selection of cultivars. Theor. Appl. Genet. 102:251-258.

Burns, M., D. Shanahan, H. Valdivia, and N. Harris. 2003. Quantitative event-specific multiplex PCR detection of Roundup Ready soya using LabChip technology. European Food Res. Technol. 216:428-433.

Carriero, F., G. Fontanazza, F. Cellini, and G. Giorio. 2002. Identification of simple sequence repeats (SSRs) in olive (Olea europaea L.). Theor. Appl. Genet. 104:301-307.

Cipriani, G., M.T. Marrazzo, R. Marconi, A. Cimato, and R. Testolin. 2002. Microsatellite markers isolated in olive (Olea europaea L.) are suitable for individual fingerprinting and reveal polymorphism within ancient cultivars. Theor. Appl. Genet. 104:223-228.

Fabbri, A., J.I. Hormaza, and V.S. Polito. 1995. Random amplified polymorphic DNA analysis of olive (Olea europaea L) cultivars. J. Amer. Soc. Hort. Sci. 120:538-542.

Ferrara, E. andF. Lamparelli. 1995. Risultati di una ricerca sessennale sul comportamento agronomico e merceologico di dieci cultivar di olivo in Puglia, p. 133-141. In: Attidel Convegno L'Olivicoltura Mediterranea. Istituto Sperimentale per l'Olivicoltura, Cosenza, Italy.

Fodale, A.S., R. Mulé, I. Muzzalupo, M. Pellegrino, and E. Perri. 2006. Caratterizzazione del germoplasma di olivo della Sicilia mediante marcatori RAPD. Italus Hortus. (In press.) 
Godino, G., N. Lombardo, I. Muzzalupo, M. Pellegrino, E. Perri, and A. Sajjad. 2005. Characterization of olive germplasm from Molise region by microsatellite markers, XVII Intl. Bot. Congr., Vienna, Austria. 17-23 July 2005. p. 359. (Abstr.).

Hartl, D.L. and A.G. Clark. 1989. Principles of population genetics, 2nd ed. Sinauer, Sunderland, Mass.

Hesse, J., J.W. Kadereit, and P. Vargas. 2000. The colonization history of Olea europaea L. in Macaronesia based on internal transcribed spacer 1 (ITS-1) sequences, randomly amplified polymorphic DNAs (RAPD), and intersimple sequence repeats (ISSR). Mol. Ecol. 9:857-868.

Khadari, B., C. Breton, N. Moutier, J.P. Roger, G. Besnard,A. Bervillé, and F. Dosba. 2003. The use of molecular markers for germplasm management in a French olive collection. Theor. Appl. Genet. 106:521-529.

Kimura, M. and J.F. Crow. 1964. The number of alleles that can be maintained in a finite population. Genetics 49:725-38.

De la Rosa, R., A. Angiolillo, C. Guerrero, M. Pellegrini, L. Rallo, G. Besnard, A. Bervillé, A. Martin, and L. Baldoni. 2003. A first linkage map of olive (Olea europaea L.) cultivars using RAPD, AFLP, RFLP and SSR markers. Theor. Appl. Genet. 106:1273-1282.

De la Rosa, R., C.M. James, and K.R. Tobutt. 2002. Isolation and characterization of polymorphic microsatellites in olive (Olea europaea L.) and their transferability to other genera in the Oleaceae. Mol. Ecol. Notes 2:265-267.

Lombardo, N., E. Perri, I. Muzzalupo, A. Madeo, G. Godino, and M. Pellegrino. 2003. Il germoplasma olivicolo calabrese. Regione Calabria Assessorato Agricoltura, Catanzaro, Italy.

Lombardo, N., G. Godino, M. Alessandrino, T. Belfiore, I. Muzzalupo, and E. Perri. 2004. Contributo alla caratterizzazione del germoplasma olivicolo pugliese. Istituto Sperimenale per l'Olivicoltura, Cosenza, Italy.

Loumou, A. and C. Giourga. 2003. Olive groves: The life and identity of the Mediterranean. Agr. Human Values 20:87-95.

Lumaret, R., N. Ouazzani, H. Michaud, G. Vivier, M.F. Deguilloux, and F. Di Giusto. 2004. Allozyme variation of Oleaster populations (wild olive tree) (Olea europaea L.) in the Mediterranean basin. Heredity 92:343-351.

Miller, M.P. 1997. Tools for population genetic analyses (TFPGA) 1.3: A Windows program for the analysis of allozyme and molecular population genetic data. Dept. Biolog. Sci., Northern Arizona Univ., Flagstaff.

Muzzalupo, I. and E. Perri. 2002. Recovery and characterization of DNA from virgin olive oil. European Food Res. Technol. 214:528-531.
Nei, M. 1972. Genetic distance between populations. Amer. Naturalist 106:283-292.

Nei, M. 1973. Analysis of gene diversity in subdivided populations. Proc. Natl. Acad. Sci. USA 70:3321-3323.

Nei, M. 1987. Molecular evolutionary genetics. Columbia Univ. Press, New York.

Perri, E., N. Lombardo, G. Godino, B. Alfei, and G. Pannelli. 2000. Caratterizzazione del germoplasma olivicolo delle Marche. Italus Hortus 7:7-11.

Perri, E., M.V. Parlati, A. Palopoli, and B. Rizzuti. 1995. Polimorfismo isoenzimatico del polline dell'olivo (Olea europaea L.). Italus Hortus 2:31-36.

Rallo, P., G. Dorado, and A. Martin. 2000. Development of simple sequence repeats (SSRs) in olive tree (Olea europaea L.). Theor. Appl. Genet. 101:984-989.

Sefc, K.M., M.S. Lopes, D. Mendonca, M. Rodrigues dos Santos, and A. Laimer da Camara Machado. 2000. Identification of microsatellite loci in olive (Olea europaea L.) and their characterization in Italian and Iberian olive trees. Mol. Ecol. 9:1171-1173.

State of Italy. 1994. Gazzetta Ufficiale n.3. Supplemento Ordinario n.2. Elenco delle varietà di olive ufficialmente iscritte nello Schedario. Istituto Poligrafico e Zecca dello Stato, Rome, Italy.

Swofford, D.L. and G.J. Olsen. 1990. Phylogeny reconstruction, p. 411-501. In: D.M. Hillis and C. Moritz (eds.). Molecular systematics. Sinauer, Sunderland, Mass.

Visioli, F., D. Caruso, S. Grande, R. Bosisio, M. Villa, G. Galli, C. Sirtori, and C. Galli. 2005. Virgin olive oil study (VOLOS): Vasoprotective potential of extra virgin olive oil in mildly dyslipidemic patients. European J. Nutr. 44:121-127.

Wiesman, Z., N. Avidan, S. Lavee, and B. Quebedeaux. 1998. Molecular characterization of common olive varieties in Israel and the West Bank using randomly amplified polymorphic DNA (RAPD) markers. J. Amer. Soc. Hort. Sci. 123:837-841.

Wu, S.B., G. Collins, and M. Sedgley. 2004. A molecular linkage map of olive (Olea europaea) based on RAPD, microsatellite, and SCARS markers. Genome 47:26-35.

Yeh, F.C., R.C. Yang, T.B.J. Boyle, Z.H. Ye, and J.X. Mao. 1997. POPGENE: The user-friendly shareware for population genetic analysis. Mol. Biol. and Biotechnol. Ctr., Univ. of Alberta, Edmonton, Alberta, Canada. 